\title{
Jaringan Syaraf Tiruan Dalam Memprediksi Tingkat Pertumbuhan Industri Mikro Dan Kecil Berdasarkan Provinsi
}

\author{
Ahmad Revi \\ Program Studi Manajemen \\ Informatika \\ AMIK Tunas Bangsa \\ ahmadrevi98@gmail.com
}

\author{
Solikhun \\ Program Studi Manajemen \\ Informatika \\ AMIK Tunas Bangsa \\ solikhun@amiktunasbangsa.ac.id
}

\author{
Iin Parlina \\ Program Studi Manajemen \\ Informatika \\ AMIK Tunas Bangsa \\ iin@amiktunasbangsa.ac.id
}

\begin{abstract}
Abstrak - Peran usaha mikro dan kecil di Indonesia yaitu sebagai dasar pondasi pembangunan nasional. Usaha industri mikro dan kecil merupakan motor inovasi dan pertumbuhan ekonomi nasional mengingat bahwa usaha mikro dan kecil adalah penyedia lapangan kerja utama serta memberikan kontribusi dalam pembentukan PDB nasional. Kontribusi sektor usaha mikro, kecil, dan menengah terhadap produk domestik bruto meningkat dari 57,84 persen menjadi 60,34 persen dalam lima tahun terakhir. Serapan tenaga kerja pada sektor ini juga meningkat, dari 96,99 persen menjadi 97,22 persen pada periode yang sama. Penelitian ini berguna untuk memberikan gambaran tentang keadaan dimasa mendatang sehingga dapat menjadi sebuah tolak ukur kepada pemerintah untuk menciptakan tindakantindakan lebih yang dapat meningkatkan perekonomian nasional. Adapun metode yang akan digunakan dalam penelitian ini adalah Jaringan Syaraf Tiruan (JST) . Dalam JST terdapat teknik peramalan yang dapat digunakan untuk melakukan prediksi yaitu backpropogation. Data yang digunakan adalah data Pertumbuhan Industri Mikro dan Kecil berdasrkan Provinsi tahun 2012 sampai tahun 2017 yang didapatkan dari Badan Pusat Statistik Nasional (online: bps.go.id). Di gunakan 5 model arsitektur Jaringan Syaraf Tiruan yaitu 5-10-1, 5-12-1, 5-14-1, 5-16-1 dan 5-18-1. Didapatkan hasil terbaik yaitu model arsitektur 5-14-1 dengan akurasi kebenaran 100\% dan MSE 0.0009999984 yang kemudian digunakan untuk prediksi.

Kata Kunci: Backpropagation, Industri Mikro dan Kecil, Jaringan Syaraf Tiruan, Peramalan/Prediksi.
\end{abstract}

\section{PENDAHULUAN}

Dalam rangka mendorong laju pertumbuhan ekonomi maka pemerintah telah melakukan tindakan berupa perhatian lebih terhadap usaha mikro dan kecil. Peran usaha mikro dan kecil di Indonesia sebagaimana halnya yang terjadi di negaranegara lain yaitu sebagai dasar pondasi pembangunan nasional. Usaha mikro adalah perusahaan industri yang tenaga kerjanya berkisar diantara 1-4 pekerja, dan usaha kecil adalah perusahaan industri yang tenaga kerjanya antara 5-19 orang. Pembangunan nasional adalah usaha peningkatan kualitas manusia dan masyarakat Indonesia secara berkelanjutan dan sesuai dengan kemampuan nasional dengan memanfaatkan ilmu pengetahuan dan teknologi serta memperhatikan tantangan-tantangan global. Tujuannya adalah mewujudkan kehidupan bangsa yang berdaulat, mandiri, maju dan sejahtera perekonomiannya. Usaha industri mikro dan kecil merupakan motor inovasi dan pertumbuhan ekonomi nasional mengingat bahwa usaha mikro dan kecil adalah penyedia lapangan kerja utama serta memberikan kontribusi dalam pembentukan PDB nasional.

Usaha mikro dan kecil umumnya menggunakan modal sendiri dengan memanfaatkan bahan-bahan di sekitarnya sehingga tahan terhadap krisis ekonomi dan bahkan penyelamat perekonomian dimasa krisis. Kedudukannya sebagai pemain utama dalam perekonomian Indonesia dapat dilihat dari sumbangannya dalam menjaga neraca pembayaran melalui kegiatan ekspor, penyedia lapangan kerja terbesar dan pencipta pasar baru dan inovasi. Kontribusi sektor usaha mikro, kecil, dan menengah terhadap produk domestik bruto meningkat dari 57,84 persen menjadi 60,34 persen dalam lima tahun terakhir. Serapan tenaga kerja pada sektor ini juga meningkat, dari 96,99 persen menjadi 97,22 persen pada periode yang sama. Meskipun indikator kontribusi terhadap pembentukan produk domestik bruto (PDB) dan serapan tenaga kerja naik, akses sektor usaha mikro, kecil, ke rantai pasok produksi global sangat minim yaitu sekitar 0,8 persen.

Untuk mengatasi masalah ini perlulah dibuat kajian untuk memprediksi pertumbuhan usaha industri mikro dan kecil guna memberikan gambaran tentang keadaan dimasa mendatang sehingga dapat menjadi sebuah tolak ukur kepada pemerintah untuk menciptakan tindakan-tindakan lebih yang dapat meningkatkan perekonomian nasional. Adapun metode yang akan digunakan dalam penelitian ini adalah Jaringan Syaraf Tiruan (JST) . Dalam JST terdapat teknik peramalan yang dapat digunakan untuk melakukan prediksi yaitu backpropogation. Dengan menggunakan teknik ini dimaksudkan untuk membuat sebuah sistem yang dapat memprediksi pertumbuhan industri mikro dan kecil 
berdasarkan provinsi. Dengan adanya sistem ini diharapkan dapat membantu mengambil keputusan untuk melakukan kegiatan-kegiatan yang menyangkut tentang peningkatan perekonomian masyarakat melalui usaha indoustri mikro dan kecil sehingga Indonesia dapat menjadi negara yang maju.

\section{METODOLOGI PENELITIAN}

\section{A. Kecerdasan Buatan (Artificial Intelligence)}

Kecerdasan buatan atau disebut juga Artificial Intelligence (AI) merupakan salah satu bagian dari ilmu komputer yang mempelajari bagaimana membuat mesin (komputer) dapat melakukan pekerjaan seperti dan sebaik yang dilakukan oleh manusia bahkan bisa lebih baik daripada yang dilakukan manusia [1]. Menurut John McCarthy dalam Dahria (2008), Artificial Intelligence (AI) adalah untuk mengetahui dan memodelkan proses-proses berpikir manusia dan mendesain mesin agar dapat menirukan perilaku manusia. Cerdas, berarti memiliki pengetahuan dan pengalaman, penalaran, bagaimana membuat keputusan dan mengambil tindakan moral yang baik [2].

\section{B. Jaringan Syaraf Tiruan}

Jaringan Saraf Tiruan (JST) merupakan salah satu representasi buatan otak manusia yang selalu mencoba untuk mensimulasikan proses pembelajaran pada otak manusia [3]. Istilah buatan digunakan karena jaringan syaraf diimplementasikan dengan menggunakan program komputer yang mampu menyelesaikan sejumlah proses perhitungan selama proses pembelajaran [4]. JST dimaksudkan untuk menghasilkan model sistem komputasi yang sesuai dengan cara kerja jaringan syaraf biologis. Model JST yang digunakan dalam penelitian ini adalah metode Backpropagation.

\section{Arsitektur Jaringan Syaraf Tiruan}

JST memiliki beberapa arsitektur jaringan yang sering digunakan dalam berbagai aplikasi. Arsitektur JST tersebut, antara lain [5] sebagai berikut :

\section{a) Jaringan Lapisan Tunggal (Single Layer Network)}

Jaringan dengan lapisan tunggal terdiri dari 1 lapisan input dan 1 lapisan output. Setiap neuron yang terdapat di dalam lapisan input selalu terhubung dengan setiap neuron yang terdapat pada lapisan output. Jaringan ini hanya menerima input kemudian secara langsung akan mengolahnya menjadi output tanpa harus melalui lapisan tersembunyi.

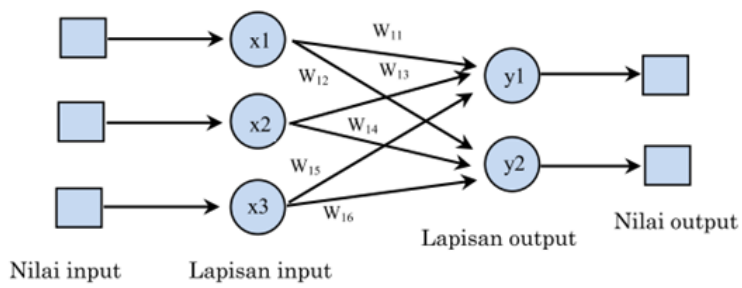

Gambar 1. Arsitektur Lapisan Tunggal. b) Jaringan Banyak Lapisan (Multilayer Net)

Jaringan dengan lapisan jamak memiliki ciri khas tertentu yaitu memiliki 3 jenis lapisan yakni lapisan input, lapisan output, dan lapisan tersembunyi. Jaringan dengan banyak lapisan ini dapat menyelesaikan permasalahan yang lebih kompleks dibandingkan jaringan dengan lapisan tunggal. Namun, proses pelatihan sering membutuhkan waktu yang cenderung lama.

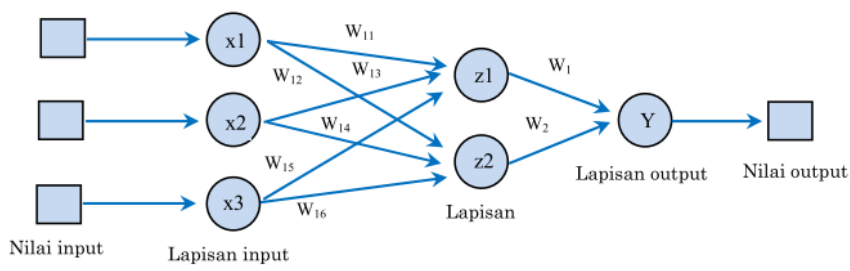

Gambar 2. Arsitektur Lapisan Multilayer.

c) Jaringan Lapisan Kompetitif (Competitive Layer)

Pada jaringan ini sekumpulan neuron bersaing untuk mendapatkan hak menjadi aktif.

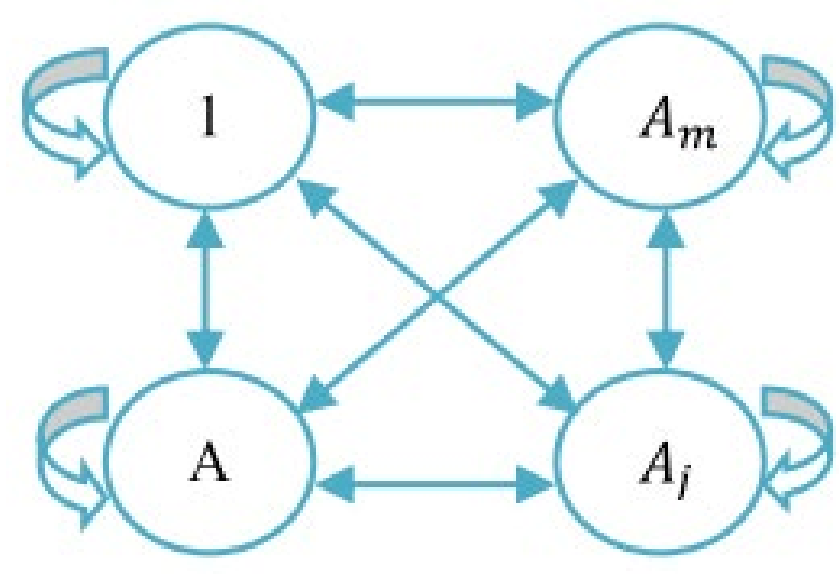

Gambar 3. Arsitektur Lapisan Kompetitif.

\section{Prediksi/Peramalan}

Prediksi/peramalan adalah proses untuk memperkirakan berapa kebutuhan dimasa yang akan datang yang meliputi kebutuhan dalam ukuran kuantitas, kualitas, waktu dan lokasi yang dibutuhkan dalam rangka memenuhi permintaan barang ataupun jasa [6].

\section{E. Model Jaringan Syaraf Tiruan yang Digunakan}

Model yang digunakan pada penelitian ini adalah model Backpropagation. Backpropagation adalah salah satu model JST yang mempunyai kemampuan mendapatkan keseimbangan antara kemampuan jaringan untuk mengenali pola yang digunakan selama pelatihan serta kemampuan jaringan untuk memberikan respon yang benar terhadap pola masukan yang serupa (tapi tidak sama) dengan pola yang dipakai selama pelatihan [7].

Terdapat 3 fase dalam pelatihan backpropagation, yaitu fase maju (feed forward), fase mundur (back propagation), dan fase modifikasi bobot. Dalam fase feed forward, pola 
masukan dihitung maju dimulai dari lapisan input hingga lapisan output. Dalam fase back propagation, tiap-tiap unit output menerima target pola yang berhubungan dengan pola input untuk dihitung nilai kesalahan. Kesalahan tersebut akan dipropagasikan mundur. Sedangkan fase modifikasi bobot bertujuan untuk menurunkan kesalahan yang terjadi. Ketiga fase tersebut diulang secara terus menerus hingga kondisi penghentian dipenuhi [8].

Secara rinci algoritma pelatihan jaringan Backpropagation dapat diuraikan sebagai berikut [9] :

- Langkah 0: Inisialisasi bobot-bobot, konstanta laju pelatihan $(\alpha)$, toleransi error atau nilai bobot (bila menggunakan nilai bobot sebagai kondisi berhenti) atau set maksimal epoch (jika menggunakan banyaknya epoch sebagai kondisi berhenti).

- Langkah 1: Selama kondisi berhenti belum dicapai, maka lakukan langkah ke-2 hingga langkah ke-9.

- Langkah 2: Untuk setiap pasangan pola pelatihan, lakukan langkah ke-3 sampai langkah ke- 8 .

- Langkah 3: Tahap I : Umpan maju (feed forward). Tiap unit masukan menerima sinyal dan meneruskannya ke unit tersembunyi di atasnya.

- Langkah 4: Masing-masing unit di lapisan tersembunyi (dari unit ke-1 hingga unit ke-p) dikalikan dengan bobotnya dan dijumlahkan serta ditambahkan dengan biasnya.

- Langkah 5: Masing-masing unit output (yk,k=1,2,3,...m) dikalikan dengan bobot dan dijumlahkan serta ditambahkan dengan biasnya.

- Langkah 6: Tahap II: Umpan mundur (backward propagation). Masing-masing unit output ( $\mathrm{yk}, \mathrm{k}=1,2,3, \ldots \mathrm{m})$ menerima pola target tk sesuai dengan pola masukan/input saat pelatihan dan kemudian informasi kesalahan/error lapisan output $(\delta \mathrm{k})$ dihitung. $\delta \mathrm{k}$ dikirim ke lapisan dibawahnya dan digunakan untuk menghitung besarnya koreksi bobot dan bias $(\Delta \mathrm{Wjk}$ dan $\Delta$ Wok ) antara lapisan tersembunyi dengan lapisan output.

- Langkah 7: Pada setiap unit di lapisan tersembunyi (dari unit ke-1 hingga ke-p; $\mathrm{i}=1 \ldots \mathrm{n} ; \mathrm{k}=1 \ldots \mathrm{m})$ dilakukan perhitungan informasi kesalahan lapisan tersembunyi $(\delta \mathrm{j})$. $\delta \mathrm{j}$ kemudian digunakan untuk menghitung besar koreksi bobot dan bias $(\Delta \mathrm{Vji}$ dan $\Delta \mathrm{Vjo})$ antara lapisan input dan lapisan tersembunyi.

- Langkah 8: Tahap III : Pengupdatean bobot dan bias. Masing-masing unit output/keluaran (yk, $\mathrm{k}=1,2,3, \ldots, \mathrm{m}$ ) dilakukan pengupdatean bias dan bobotnya $(j=0,1,2, \ldots p)$ sehingga menghasilkan bobot dan bias baru. Demikian juga untuk setiap unit tersembunyi mulai dari unit ke-1 sampai dengan unit ke-p dilakukan pengupdatean bobot dan bias.

- Langkah 9 : Uji kondisi berhenti (akhir iterasi).

F. Langkah-Langkah Penelitian

Penelitian dilakukan dengan sistematis dan alur yang baik agar didapatkan hasil yang sesuai dengan target sehingga dapat dijadikan bahan referensi bagi para peneliti lain. Adapun langkah yang dilakukan yaitu:

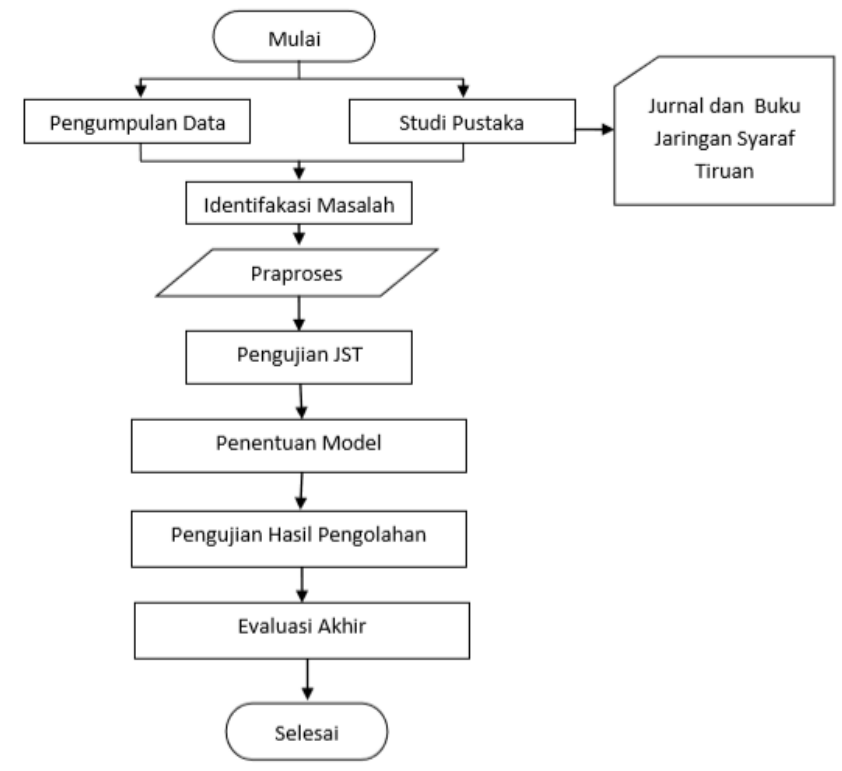

Gambar 4. Langkah-Langkah Penelitian

Keterangan Kerangka Kerja :

a) Pengumpulan Data

Pengumpulan data dilakukan untuk memperoleh informasi yang dibutuhkan dalam rangka mencapai tujuan penelitian. Data dikumpulkan dari sampel yang telah ditentukan sebelumnya. Sampel tersebut terdiri atas sekumpulan unit analisis sebagai sasaran penelitian.

b) Studi Pustaka

Untuk mencapai tujuan yang akan ditentukan, maka perlu dipelajari beberapa literatur-literatur yang digunakan. Studi pustaka merupakan langkah awal dalam penelitian ini, studi pustaka ini dilakukan untuk melengkapi pengetahuan dasar dan teori-teori yang digunakan dalam penelitian ini.

c) Identifikasi Masalah

Pada tahap identifikasi masalah ini, dilakukan setelah semua data-data terpenuhi kemudian didapatkan dataset yang sesuai untuk dilakukan proses pada tahap konversi data yang didapat sesuai dengan bobot yang ditentukan.

d) Praproses

Tahap praproses merupakan tahap seleksi data yang bertujuan untuk mendapatkan data yang bersih dan siap untuk digunakan dalam penelitian.

e) Pengujian Jaringan Saraf Tiruan

Setelah mendapatkan data yang cukup maka proses pengujian dan pelatihan data diolah dengan menggunakan algoritma Backpropagation.

f) Penentuan Model

Pada tahap ini akan dilakukan penentuan model jaringan syaraf tiruan dengan metode Backpropagation. Hasil dari tahap ini adalah untuk mendapatkan pola yang terbaik jaringan syaraf tiruan dengan metode Backpropagation.

g) Pengujian Hasil Pengolahan Data

Setelah proses penentuan model selesai, maka dilakukan tahapan uji coba terhadap hasil pengolahan data dari hasil desain program. Apakah desain program yang dibuat telah sesuai dengan apa yang diharapkan. 
h) Evaluasi Akhir

Evaluasi akhir dilakukan untuk mengetahui apakah sistem yang dirancang tersebut sesuai dengan yang diharapkan. Evaluasi dilakukan untuk membandingkan hasil yang diharapkan pada tahap implementasin sistem yang dibuat secara manual dengan sistem yang dibuat menggunakan software Matlab.

\section{HASIL DAN PEMBAHASAN}

A. Perancangan Sistem

a) Pendefenisian Input dan Target

Data pertumbuhan industri mikro dan kecil selanjutnya akan diolah oleh JST dengan metode Backpropagation. Agar data dapat dikenali, maka data harus ditransformasikan kedalam bentuk bilangan antara 0 sampai 1 (logsig). Data yang digunakan meliputi data pertumbuhan industri mikro dan kecil dari tahun 2012 sampai tahun 2017 yang diperoleh website dari Badan Pusat Statistik. Data-data yang digunakan diperoleh berdasarkan kategori dari masingmasing variabel selain juga untuk memudahkan mengingat dalam pendefinisiannya.

\section{b) Pendefenisian Input}

Variabel data yang dipakai adalah kriteria yang menjadi acuan dalam pengambil keputusan. Variabel ditentukan dengan cara melihat ketergantungan data terhadap penelitian yang dilakukan. Adapun daftar variabel dalam memprediksi Data Pertumubuhan Industri Mikro dan Kecil dapat dilihat pada tabel 1 berikut:

Tabel 1. Daftar Kriteria Data Pertumbuhan Industri Mikro dan Kecil.

\begin{tabular}{rlc} 
No & Variabel & Nama Kriteria \\
1 & X1 & Data Tahun 2012 \\
\hline 2 & X2 & Data Tahun 2013 \\
\hline 3 & X3 & Data Tahun 2014 \\
\hline 4 & X4 & Data Tahun 2015 \\
\hline 5 & X5 & Data Tahun 2016 \\
\hline
\end{tabular}

Data sampel yang digunakan adalah Pertumbuhan Industri Mikro dan Kecil Berdasarkan Provinsi dari Tahun 2012 sampai tahun 2017 yang terdiri dari 33 data lengkap tiap provinsi dimana untuk pelatihan digunakan data 1 sampai 17 dan untuk pengujian digunakan data 18 sampai 33 dengan masing-masing data memiliki 5 variabel dan 1 target. Data ini nantinya akan ditransformasikan ke sebuah data antara 0 sampai 1 sebelum dilakukan pelatihan dan pengujian menggunakan Jaringan Saraf Tiruan metode Backpropagation dengan rumus :

$x^{\prime}=\frac{0,8(x-x \min )}{x \cdot \max -x \cdot \min }+0,1$ c) Pendefenisian Target

Adapun target yang digunakan adalah data Pertumbuhan Industri Mikro dan Kecil pada tahun 2017.

\section{d) Pendefenisian Output}

Hasil yang diharapkan pada tahap pendefenisian ini adalah untuk mencari pola menentukan nilai terbaik untuk memprediksi Pertumbuhan Industri Mikro dan Kecil Berdasarkan Provinsi. Hasil pengujian berfungsi sebagai berikut :

- Untuk mengetahui prediksi Pertumbuhan Industri Mikro dan Kecil Berdasarkan Provinsi yang didasarkan pada Data Pertumbuhan Industri Mikro dan Kecil Berdasarkan Provinsi. Output dari prediksi ini adalah pola arsitektur terbaik untuk memprediksi Pertumbuhan Industri Mikro dan Kecil Berdasarkan Provinsi dengan melihat error minimum.

- Kategorisasi Output pelatihan (train) dan pengujian (test) Kategori untuk output ditentukan oleh tingkat error minimum dari target. Batasan kategori tersebut terdapat pada tabel berikut:

Tabel 2. Data Kategorisasi.

\begin{tabular}{rll} 
No & Keterangan & Error Minimum \\
\hline 1 & Benar & $0.001-0.05$ \\
\hline 2 & Salah & $>0.05$ \\
\hline
\end{tabular}

\section{B. Pengolahan Data}

Pengolahan data dilakukan dengan bantuan Matlab aplikasi perangkat lunak. Sampel data adalah Pertumbuhan Industri Mikro dan Kecil Berdasarkan Provinsi. Data ini akan digunakan pada data pelatihan dan data pengujian. Sampel data yang telah diproses dan ditranformasikan adalah sebagai berikut :

Tabel 3. Data Mentah.

\begin{tabular}{|c|c|c|c|c|c|c|c|}
\hline \multirow{2}{*}{ No } & \multirow{2}{*}{ Provinsi } & \multicolumn{6}{|c|}{ Tahun } \\
\hline & & 2012 & 2013 & 2014 & 2015 & 2016 & 2017 \\
\hline 1 & Aceh & 102.2 & 95.81 & 105.08 & 108.44 & 110.86 & 131.85 \\
\hline 2 & $\begin{array}{l}\text { Sumatera } \\
\text { Utara }\end{array}$ & 100.7 & 104.08 & 108.69 & 114.75 & 125.5 & 126.16 \\
\hline 3 & $\begin{array}{l}\text { Sumatera } \\
\text { Barat }\end{array}$ & 97.09 & 104.65 & 102.32 & 104.24 & 108.22 & 105.64 \\
\hline 4 & Riau & 96.8 & 101.56 & 106.58 & 103.44 & 101.35 & 112.5 \\
\hline 5 & Jambi & 88.41 & 87.7 & 89.21 & 98.42 & 103.77 & 117.59 \\
\hline 6 & $\begin{array}{l}\text { Sumatera } \\
\text { Selatan }\end{array}$ & 102.51 & 104.12 & 109.87 & 102.06 & 110.34 & 115.55 \\
\hline 7 & Bengkulu & 93.78 & 90.11 & 99.29 & 107.4 & 115.18 & 125.77 \\
\hline 8 & Lampung & 104.36 & 100.84 & 104.97 & 114.03 & 120.79 & 122.05 \\
\hline 9 & $\begin{array}{l}\text { Kep. } \\
\text { Bangka } \\
\text { Belitung }\end{array}$ & 101.14 & 100.66 & 100.91 & 95.94 & 87.34 & 95.61 \\
\hline 10 & Kep. Riau & 96.99 & 98.8 & 107.44 & 120.29 & 121.05 & 130.7 \\
\hline 11 & Dki Jakarta & 106.97 & 120.26 & 127.12 & 138.55 & 150.24 & 167.19 \\
\hline 12 & Jawa Barat & 101.73 & 113.25 & 114.63 & 117.11 & 115.56 & 116.64 \\
\hline 13 & $\begin{array}{l}\text { Jawa } \\
\text { Tengah }\end{array}$ & 104.41 & 114.94 & 118.35 & 124.92 & 127.52 & 124.17 \\
\hline
\end{tabular}




\begin{tabular}{|c|c|c|c|c|c|c|c|}
\hline 14 & $\begin{array}{l}\text { DI } \\
\text { Yogyakarta }\end{array}$ & 94.73 & 107.08 & 111.04 & 114.87 & 121.22 & 136.23 \\
\hline 15 & Jawa Timur & 104.77 & 113.75 & 118.23 & 124.02 & 126.55 & 129.67 \\
\hline 16 & Banten & 110.74 & 111.29 & 118.1 & 120.4 & 131.04 & 151.91 \\
\hline 17 & Bali & 98.32 & 117.21 & 122.01 & 135.81 & 147.37 & 151.48 \\
\hline 18 & $\begin{array}{l}\text { Nusa } \\
\text { Tenggara } \\
\text { Barat }\end{array}$ & 105.42 & 111.89 & 118.15 & 110.88 & 106.9 & 106.83 \\
\hline 19 & $\begin{array}{l}\text { Nusa } \\
\text { Tenggara } \\
\text { Timur } \\
\end{array}$ & 105.29 & 103.53 & 106.49 & 112.52 & 128.51 & 154.11 \\
\hline 20 & $\begin{array}{l}\text { Kalimantan } \\
\text { Barat }\end{array}$ & 106.96 & 113 & 112.64 & 117.99 & 119.82 & 123.8 \\
\hline 21 & $\begin{array}{l}\text { Kalimantan } \\
\text { Tengah }\end{array}$ & 95.68 & 90.81 & 95.55 & 106.32 & 109.1 & 129.9 \\
\hline 22 & $\begin{array}{l}\text { Kalimantan } \\
\text { Selatan }\end{array}$ & 99.5 & 108.08 & 112.99 & 121.66 & 136.27 & 153.46 \\
\hline 23 & $\begin{array}{l}\text { Kalimantan } \\
\text { Timur }\end{array}$ & 95.79 & 106.35 & 109.04 & 111.37 & 128.7 & 136.28 \\
\hline 24 & $\begin{array}{l}\text { Sulawesi } \\
\text { Utara }\end{array}$ & 94.88 & 95.49 & 99.06 & 103.37 & 105.01 & 110 \\
\hline 25 & $\begin{array}{l}\text { Sulawesi } \\
\text { Tengah }\end{array}$ & 109.44 & 113.6 & 127.8 & 134.36 & 149.05 & 154.23 \\
\hline 26 & $\begin{array}{l}\text { Sulawesi } \\
\text { Selatan }\end{array}$ & 110.41 & 103.87 & 115.4 & 117.52 & 121.6 & 121.59 \\
\hline 27 & $\begin{array}{l}\text { Sulawesi } \\
\text { Tenggara }\end{array}$ & 107.86 & 113.01 & 128.09 & 128.46 & 138.04 & 156.98 \\
\hline 28 & Gorontalo & 97.06 & 111.66 & 113.19 & 128.09 & 143.72 & 159.35 \\
\hline 29 & $\begin{array}{l}\text { Sulawesi } \\
\text { Barat }\end{array}$ & 104.65 & 105.94 & 111.34 & 126.25 & 146.64 & 166.98 \\
\hline 30 & Maluku & 102.92 & 108.92 & 116.44 & 136.79 & 160.34 & 177.95 \\
\hline 31 & $\begin{array}{l}\text { Maluku } \\
\text { Utara }\end{array}$ & 103.33 & 121.42 & 130.74 & 145.61 & 169.8 & 191.66 \\
\hline 32 & $\begin{array}{l}\text { Papua } \\
\text { Barat }\end{array}$ & 105.56 & 100.39 & 106.49 & 122.93 & 132.7 & 137.01 \\
\hline 33 & Papua & 98.32 & 95.73 & 97.76 & 104.44 & 120.23 & 139.36 \\
\hline
\end{tabular}

Sumber : Diolah dari Badan Pusat Statistik (www.bps.go.id)

Tabel 4. Sampel dari Data yang Telah Ditransformasikan.

\begin{tabular}{|c|c|c|c|c|c|c|c|}
\hline \multirow{2}{*}{ No } & \multirow{2}{*}{ Data Ke- } & \multicolumn{6}{|c|}{ Transformasi } \\
\hline & & $\mathbf{X 1}$ & $\mathbf{X} 2$ & $\mathbf{X 3}$ & $\mathrm{X} 4$ & X5 & Target \\
\hline 1 & Data 1 & 0.2140 & 0.1650 & 0.2360 & 0.2618 & 0.2804 & 0.4413 \\
\hline 2 & Data 2 & 0.2025 & 0.2284 & 0.2637 & 0.3102 & 0.3926 & 0.3977 \\
\hline 3 & Data 3 & 0.1748 & 0.2327 & 0.2149 & 0.2296 & 0.2601 & 0.2403 \\
\hline 4 & Data 4 & 0.1725 & 0.2090 & 0.2475 & 0.2235 & 0.2074 & 0.2929 \\
\hline 5 & Data 5 & 0.1082 & 0.1028 & 0.1143 & 0.1850 & 0.2260 & 0.3320 \\
\hline 6 & Data 6 & 0.2163 & 0.2287 & 0.2728 & 0.2129 & 0.2764 & 0.3163 \\
\hline 7 & Data 7 & 0.1494 & 0.1212 & 0.1916 & 0.2538 & 0.3135 & 0.3947 \\
\hline 8 & Data 8 & 0.2305 & 0.2035 & 0.2352 & 0.3047 & 0.3565 & 0.3662 \\
\hline 9 & Data 9 & 0.2058 & 0.2021 & 0.2041 & 0.1660 & 0.1000 & 0.1634 \\
\hline 10 & Data 10 & 0.1740 & 0.1879 & 0.2541 & 0.3527 & 0.3585 & 0.4325 \\
\hline 11 & Data 11 & 0.2505 & 0.3525 & 0.4051 & 0.4927 & 0.5824 & 0.7123 \\
\hline 12 & Data 12 & 0.2104 & 0.2987 & 0.3093 & 0.3283 & 0.3164 & 0.3247 \\
\hline 13 & Data 13 & 0.2309 & 0.3117 & 0.3378 & 0.3882 & 0.4081 & 0.3824 \\
\hline 14 & Data 14 & 0.1567 & 0.2514 & 0.2817 & 0.3111 & 0.3598 & 0.4749 \\
\hline 15 & Data 15 & 0.2337 & 0.3025 & 0.3369 & 0.3813 & 0.4007 & 0.4246 \\
\hline 16 & Data 16 & 0.2794 & 0.2837 & 0.3359 & 0.3535 & 0.4351 & 0.5952 \\
\hline 17 & Data 17 & 0.1842 & 0.3291 & 0.3659 & 0.4717 & 0.5604 & 0.5919 \\
\hline 18 & Data 18 & 0.2387 & 0.2883 & 0.3363 & 0.2805 & 0.2500 & 0.2495 \\
\hline
\end{tabular}

\begin{tabular}{llllllll}
\hline $\mathbf{1 9}$ & Data 19 & 0.2377 & 0.2242 & 0.2469 & 0.2931 & 0.4157 & 0.6120 \\
\hline $\mathbf{2 0}$ & Data 20 & 0.2505 & 0.2968 & 0.2940 & 0.3350 & 0.3491 & 0.3796 \\
\hline $\mathbf{2 1}$ & Data 21 & 0.1640 & 0.1266 & 0.1630 & 0.2456 & 0.2669 & 0.4264 \\
\hline $\mathbf{2 2}$ & Data 22 & 0.1933 & 0.2590 & 0.2967 & 0.3632 & 0.4752 & 0.6071 \\
\hline $\mathbf{2 3}$ & Data 23 & 0.1648 & 0.2458 & 0.2664 & 0.2843 & 0.4172 & 0.4753 \\
\hline $\mathbf{2 4}$ & Data 24 & 0.1578 & 0.1625 & 0.1899 & 0.2229 & 0.2355 & 0.2738 \\
\hline $\mathbf{2 5}$ & Data 25 & 0.2695 & 0.3014 & 0.4103 & 0.4606 & 0.5732 & 0.6130 \\
\hline $\mathbf{2 6}$ & Data 26 & 0.2769 & 0.2268 & 0.3152 & 0.3314 & 0.3627 & 0.3627 \\
\hline $\mathbf{2 7}$ & Data 27 & 0.2574 & 0.2969 & 0.4125 & 0.4153 & 0.4888 & 0.6340 \\
\hline $\mathbf{2 8}$ & Data 28 & 0.1745 & 0.2865 & 0.2982 & 0.4125 & 0.5324 & 0.6522 \\
\hline $\mathbf{2 9}$ & Data 29 & 0.2327 & 0.2426 & 0.2840 & 0.3984 & 0.5548 & 0.7107 \\
\hline $\mathbf{3 0}$ & Data 30 & 0.2195 & 0.2655 & 0.3232 & 0.4792 & 0.6598 & 0.7949 \\
\hline $\mathbf{3 1}$ & Data 31 & 0.2226 & 0.3613 & 0.4328 & 0.5469 & 0.7324 & 0.9000 \\
\hline $\mathbf{3 2}$ & Data 32 & 0.2397 & 0.2001 & 0.2469 & 0.3729 & 0.4479 & 0.4809 \\
\hline $\mathbf{3 3}$ & Data 33 & 0.1842 & 0.1643 & 0.1799 & 0.2311 & 0.3522 & 0.4989 \\
\hline
\end{tabular}

C. Perancangan Arsitektur Jaringan Syaraf Tiruan

Jaringan syaraf tiruan yang digunakan adalah dengan langkah pembelajaran feedforward untuk memprediksi pertumbuhan Industri Mikro dan Kecil berdasarkan provinsi dengan menggunakan fungsi training traingd. Jaringan ini memiliki beberapa lapisan, yaitu lapisan masukan (input), lapisan keluaran (output) dan beberapa lapisan tersembunyi (hidden). Lapisan tersembunyi tersebut membantu jaringan untuk dapat mengenali lebih banyak pola masukan dibandingkan dengan jaringan yang tidak memiliki lapisan tersembunyi. Parameter-parameter dalam pembentukan jaringan Backpropagation menggunakan 5 variabel masukan, 1 lapisan tersembunyi dan 1 lapisan keluaran. Adapun model arsitektur yang akan digunakan untuk mendapatkan arsitektur terbaik adalah 5-10-1, 5-12-1, 5-141, 5-16-1 dan 5-18-1.

Tahapan-tahapan yang akan dilakukan dalam pengguna algoritma propagasi balik dengan fungsi aktivasi sigmoid. Tahapan yang harus dilakukan adalah sebagi berikut:

- Inisialisasi (initialization), merupakan tahap di mana variabel-variabel nilai akan didefinisikan terlebih dahulu, misalnya seperti: nilai data input, weight, nilai output yang diharapkan, learning rate dan nilai-nilai data lainnya.

- Aktivasi (activation), merupakan proses perhitungan terhadap nilai aktual output pada hidden layer dan menghitung nilai actual output pada output layer.

- Weight Training, merupakan proses perhitungan nilai error gradient pada output layer dan menghitung nilai error gradient pada hidden layer

- Iteration, merupakan tahap akhir dalam penggujian, dimana jika masih terjadi error minimum yang diharapkan belum ditemukan maka kembali pada tahap aktivasi (activation).

Arsitektur yang digunakan pada jaringan syaraf tiruan ini memiliki karakteristik arsitektur jaringan sebagai berikut : 
Tabel 5. Arsitektur Jaringan.

\begin{tabular}{ll}
\multicolumn{1}{c}{ Karakteristik } & \multicolumn{1}{c}{ Spesifikasi } \\
\hline Arsitektur & 1 hidden layer \\
\hline Input Data & 5 \\
\hline Output Data & 1 \\
\hline Training Function & Traingd \\
\hline Activation Function & Sigmoid \\
\hline Goal & 0,001 \\
\hline Maximum Epoch & 1000000 \\
\hline Learning Rate & 0,01 \\
\hline
\end{tabular}

a) Pelatihan dan Pengujian Arsitektur 5-10-1

Data yang digunakan dalam melakukan pelatihan adalah 17 data pertama tahun 2012 sampai tahun 2016 dengan target data tahun 2017 dan pengujiannya menggunakan data dari 16 data terakhir tahun 2012 sampai tahun 2016 dengan target data tahun 2017. Berikut ini adalah hasil pelatihan dan pengujian data menggunakan arsitektur 5-10-1. Data hasil pelatihan dan pengujian dapat dilihat sebagai berikut:

Tabel 6. Pelatihan dan Pengujian Model 5-10-1.

\begin{tabular}{lcclcccc}
\hline \multicolumn{6}{c}{ Pelatihan } & & \multicolumn{5}{c}{ Pengujian } \\
\hline Target & Output & Error & SSE & Target & Output & Error & SSE \\
\hline 0.4413 & 0.3971 & 0.0442 & 0.0020 & 0.2495 & 0.3116 & -0.0621 & 0.0039 \\
\hline 0.3977 & 0.3871 & 0.0106 & 0.0001 & 0.6120 & 0.4338 & 0.1782 & 0.0318 \\
\hline 0.2403 & 0.2613 & -0.0210 & 0.0004 & 0.3796 & 0.3677 & 0.0119 & 0.0001 \\
\hline 0.2929 & 0.2636 & 0.0293 & 0.0009 & 0.4264 & 0.3575 & 0.0689 & 0.0048 \\
\hline 0.3320 & 0.3415 & -0.0095 & 0.0001 & 0.6071 & 0.4237 & 0.1834 & 0.0336 \\
\hline 0.3163 & 0.3177 & -0.0014 & 0.0000 & 0.4753 & 0.3645 & 0.1108 & 0.0123 \\
\hline 0.3947 & 0.3962 & -0.0015 & 0.0000 & 0.2738 & 0.3318 & -0.0580 & 0.0034 \\
\hline 0.3662 & 0.3808 & -0.0146 & 0.0002 & 0.6130 & 0.7293 & -0.1163 & 0.0135 \\
\hline 0.1634 & 0.1711 & -0.0077 & 0.0001 & 0.3627 & 0.5257 & -0.1630 & 0.0266 \\
\hline 0.4325 & 0.4738 & -0.0413 & 0.0017 & 0.6340 & 0.7234 & -0.0894 & 0.0080 \\
\hline 0.7123 & 0.6858 & 0.0265 & 0.0007 & 0.6522 & 0.4462 & 0.2060 & 0.0424 \\
\hline 0.3247 & 0.3276 & -0.0029 & 0.0000 & 0.7107 & 0.4365 & 0.2742 & 0.0752 \\
\hline 0.3824 & 0.4474 & -0.0650 & 0.0042 & 0.7949 & 0.4828 & 0.3121 & 0.0974 \\
\hline 0.4749 & 0.3996 & 0.0753 & 0.0057 & 0.9000 & 0.7570 & 0.1430 & 0.0205 \\
\hline 0.4246 & 0.4499 & -0.0253 & 0.0006 & 0.4809 & 0.3939 & 0.0870 & 0.0076 \\
\hline 0.5952 & 0.5791 & 0.0161 & 0.0003 & 0.4989 & 0.3470 & 0.1519 & 0.0231 \\
\hline 0.5919 & 0.5993 & -0.0074 & 0.0001 & & Total & $\mathbf{0 . 4 0 4 0 1 4 4 8 0 0}$ \\
\hline & Total & $\mathbf{0 . 0 1 6 9 9 9 9 1 7 8}$ & & MSE & $\mathbf{0 . 0 2 5 2 5 0 9 0 5 0}$ \\
\hline & $\mathbf{M S E}$ & $\mathbf{0 . 0 0 0 9 9 9 9 9 5 2}$ & & $\mathbf{A k u r a s i}$ & & $\mathbf{8 8 \%}$
\end{tabular}

b) Pelatihan dan Pengujian Arsitektur 5-12-1

Berikut ini adalah hasil pelatihan dan pengujian data menggunakan arsitektur 5-12-1. Data hasil pelatihan dan pengujian dapat dilihat sebagai berikut :
Tabel 7. Pelatihan dan Pengujian Model 5-12-1.

\begin{tabular}{|c|c|c|c|c|c|c|c|}
\hline \multicolumn{4}{|c|}{ Pelatihan } & \multicolumn{4}{|c|}{ Pengujian } \\
\hline Target & Output & Eror & SSE & Target & Output & Eror & SSE \\
\hline 0.4413 & 0.3758 & 0.0655 & 0.0043 & 0.2495 & 0.3743 & -0.1248 & 0.0156 \\
\hline 0.3977 & 0.4207 & -0.0230 & 0.0005 & 0.6120 & 0.4388 & 0.1732 & 0.0300 \\
\hline 0.2403 & 0.2313 & 0.0090 & 0.0001 & 0.3796 & 0.2649 & 0.1147 & 0.0132 \\
\hline 0.2929 & 0.3384 & -0.0455 & 0.0021 & 0.4264 & 0.2945 & 0.1319 & 0.0174 \\
\hline 0.3320 & 0.3466 & -0.0146 & 0.0002 & 0.6071 & 0.5151 & 0.0920 & 0.0085 \\
\hline 0.3163 & 0.3599 & -0.0436 & 0.0019 & 0.4753 & 0.4455 & 0.0298 & 0.0009 \\
\hline 0.3947 & 0.3831 & 0.0116 & 0.0001 & 0.2738 & 0.3387 & -0.0649 & 0.0042 \\
\hline 0.3662 & 0.3629 & 0.0033 & 0.0000 & 0.6130 & 0.7929 & -0.1799 & 0.0324 \\
\hline 0.1634 & 0.1825 & -0.0191 & 0.0004 & 0.3627 & 0.5699 & -0.2072 & 0.0429 \\
\hline 0.4325 & 0.4445 & -0.0120 & 0.0001 & 0.6340 & 0.7680 & -0.1340 & 0.0180 \\
\hline 0.7123 & 0.7108 & 0.0015 & 0.0000 & 0.6522 & 0.4390 & 0.2132 & 0.0455 \\
\hline 0.3247 & 0.2736 & 0.0511 & 0.0026 & 0.7107 & 0.6026 & 0.1081 & 0.0117 \\
\hline 0.3824 & 0.4202 & -0.0378 & 0.0014 & 0.7949 & 0.7121 & 0.0828 & 0.0069 \\
\hline 0.4749 & 0.4227 & 0.0522 & 0.0027 & 0.9000 & 0.7517 & 0.1483 & 0.0220 \\
\hline 0.4246 & 0.4326 & -0.0080 & 0.0001 & 0.4809 & 0.4901 & -0.0092 & 0.0001 \\
\hline 0.5952 & 0.5766 & 0.0186 & 0.0003 & 0.4989 & 0.2470 & 0.2519 & 0.0635 \\
\hline \multirow[t]{3}{*}{0.5919} & 0.6010 & -0.0091 & 0.0001 & & Total & \multicolumn{2}{|c|}{0.3325470094} \\
\hline & Total & \multicolumn{2}{|c|}{0.0169998793} & & MSE & \multicolumn{2}{|c|}{0.0207841881} \\
\hline & MSE & \multicolumn{2}{|c|}{0.0009999929} & & Akurasi & & $94 \%$ \\
\hline
\end{tabular}

c) Pelatihan dan Pengujian Arsitektur 5-14-1

Berikut ini adalah hasil pelatihan dan pengujian data menggunakan arsitektur 5-14-1. Data hasil pelatihan dan pengujian dapat dilihat sebagai berikut :

Tabel 8. Pelatihan dan Pengujian Model 5-14-1.

\begin{tabular}{llllllll}
\multicolumn{6}{c}{ Pelatihan } & & \multicolumn{5}{c}{ Pengujian } \\
Target & Output & Eror & SSE & Target & Output & Eror & SSE \\
\hline 0.4413 & 0.4096 & 0.0317 & 0.0010 & 0.2495 & 0.2939 & -0.0444 & 0.0020 \\
\hline 0.3977 & 0.4578 & -0.0601 & 0.0036 & 0.6120 & 0.4427 & 0.1693 & 0.0287 \\
\hline 0.2403 & 0.2523 & -0.0120 & 0.0001 & 0.3796 & 0.2656 & 0.1140 & 0.0130 \\
\hline 0.2929 & 0.2941 & -0.0012 & 0.0000 & 0.4264 & 0.3320 & 0.0944 & 0.0089 \\
\hline 0.3320 & 0.3363 & -0.0043 & 0.0000 & 0.6071 & 0.5153 & 0.0918 & 0.0084 \\
\hline 0.3163 & 0.3608 & -0.0445 & 0.0020 & 0.4753 & 0.4666 & 0.0087 & 0.0001 \\
\hline 0.3947 & 0.4100 & -0.0153 & 0.0002 & 0.2738 & 0.3084 & -0.0346 & 0.0012 \\
\hline 0.3662 & 0.3475 & 0.0187 & 0.0004 & 0.6130 & 0.7732 & -0.1602 & 0.0257 \\
\hline 0.1634 & 0.1438 & 0.0196 & 0.0004 & 0.3627 & 0.3963 & -0.0336 & 0.0011 \\
\hline 0.4325 & 0.4419 & -0.0094 & 0.0001 & 0.6340 & 0.7629 & -0.1289 & 0.0166 \\
\hline 0.7123 & 0.7170 & -0.0047 & 0.0000 & 0.6522 & 0.5070 & 0.1452 & 0.0211 \\
\hline 0.3247 & 0.2919 & 0.0328 & 0.0011 & 0.7107 & 0.7146 & -0.0039 & 0.0000 \\
\hline 0.3824 & 0.4249 & -0.0425 & 0.0018 & 0.7949 & 0.7846 & 0.0103 & 0.0001 \\
\hline 0.4749 & 0.4018 & 0.0731 & 0.0053 & 0.9000 & 0.8261 & 0.0739 & 0.0055 \\
\hline & & & & & & & \\
\hline
\end{tabular}




\begin{tabular}{rccccccc}
\hline 0.4246 & 0.4203 & 0.0043 & 0.0000 & 0.4809 & 0.4135 & 0.0674 & 0.0045 \\
\hline 0.5952 & 0.5651 & 0.0301 & 0.0009 & 0.4989 & 0.3872 & 0.1117 & 0.0125 \\
\hline 0.5919 & 0.5898 & 0.0021 & 0.0000 & & Total & $\mathbf{0 . 1 4 9 3 4 8 4 6 2 8}$ \\
\hline & Total & $\mathbf{0 . 0 1 6 9 9 9 9 7 3 0}$ & MSE & $\mathbf{0 . 0 0 9 3 3 4 2 7 8 9}$ \\
\hline & MSE & $\mathbf{0 . 0 0 0 9 9 9 9 9 8 4}$ & & Akurasi & & $\mathbf{1 0 0 \%}$
\end{tabular}

d) Pelatihan dan Pengujian Arsitektur 5-16-1

Berikut ini adalah hasil pelatihan dan pengujian data menggunakan arsitektur 5-16-1. Data hasil pelatihan dan pengujian dapat dilihat sebagai berikut :

Tabel 9. Pelatihan dan Pengujian Model 5-16-1.

\begin{tabular}{|c|c|c|c|c|c|c|c|}
\hline \multicolumn{4}{|c|}{ Pelatihan } & \multicolumn{4}{|c|}{ Pengujian } \\
\hline Target & Output & Eror & SSE & Target & Output & Eror & SSE \\
\hline 0.4413 & 0.3742 & 0.0671 & 0.0045 & 0.2495 & 0.4853 & -0.2358 & 0.0556 \\
\hline 0.3977 & 0.3954 & 0.0023 & 0.0000 & 0.6120 & 0.3810 & 0.2310 & 0.0534 \\
\hline 0.2403 & 0.2465 & -0.0062 & 0.0000 & 0.3796 & 0.3823 & -0.0027 & 0.0000 \\
\hline 0.2929 & 0.3074 & -0.0145 & 0.0002 & 0.4264 & 0.3365 & 0.0899 & 0.0081 \\
\hline 0.3320 & 0.3052 & 0.0268 & 0.0007 & 0.6071 & 0.3812 & 0.2259 & 0.0510 \\
\hline 0.3163 & 0.3417 & -0.0254 & 0.0006 & 0.4753 & 0.4109 & 0.0644 & 0.0041 \\
\hline 0.3947 & 0.4119 & -0.0172 & 0.0003 & 0.2738 & 0.3035 & -0.0297 & 0.0009 \\
\hline 0.3662 & 0.3416 & 0.0246 & 0.0006 & 0.6130 & 0.5940 & 0.0190 & 0.0004 \\
\hline 0.1634 & 0.2010 & -0.0376 & 0.0014 & 0.3627 & 0.5511 & -0.1884 & 0.0355 \\
\hline 0.4325 & 0.5002 & -0.0677 & 0.0046 & 0.6340 & 0.4918 & 0.1422 & 0.0202 \\
\hline 0.7123 & 0.6933 & 0.0190 & 0.0004 & 0.6522 & 0.5459 & 0.1063 & 0.0113 \\
\hline 0.3247 & 0.3301 & -0.0054 & 0.0000 & 0.7107 & 0.5238 & 0.1869 & 0.0349 \\
\hline 0.3824 & 0.3913 & -0.0089 & 0.0001 & 0.7949 & 0.7044 & 0.0905 & 0.0082 \\
\hline 0.4749 & 0.4189 & 0.0560 & 0.0031 & 0.9000 & 0.8464 & 0.0536 & 0.0029 \\
\hline 0.4246 & 0.4147 & 0.0099 & 0.0001 & 0.4809 & 0.4682 & 0.0127 & 0.0002 \\
\hline 0.5952 & 0.6060 & -0.0108 & 0.0001 & 0.4989 & 0.3907 & 0.1082 & 0.0117 \\
\hline \multirow[t]{3}{*}{0.5919} & 0.6048 & -0.0129 & 0.0002 & & Total & \multicolumn{2}{|c|}{0.2983516848} \\
\hline & Total & \multicolumn{2}{|c|}{0.0169998754} & & MSE & \multicolumn{2}{|c|}{0.018646980} \\
\hline & MSE & \multicolumn{2}{|c|}{0.0009999927} & & Akurasi & & $81 \%$ \\
\hline
\end{tabular}

e) Pelatihan dan Pengujian Arsitektur 5-18-1

Berikut ini adalah hasil pelatihan dan pengujian data menggunakan arsitektur 5-18-1. Data hasil pelatihan dan pengujian dapat dilihat sebagai berikut :

Tabel 10. Pelatihan dan Pengujian Model 5-18-1

\begin{tabular}{ccllcccc}
\hline \multicolumn{3}{c}{ Pelatihan } & \multicolumn{5}{c}{ Pengujian } \\
Target & Output & Eror & SSE & Target & Output & Eror & SSE \\
\hline 0.4413 & 0.4035 & 0.0378 & 0.0014 & 0.2495 & 0.4030 & -0.1535 & 0.0236 \\
\hline 0.3977 & 0.4101 & -0.0124 & 0.0002 & 0.6120 & 0.3946 & 0.2174 & 0.0473 \\
\hline 0.2403 & 0.2434 & -0.0031 & 0.0000 & 0.3796 & 0.3047 & 0.0749 & 0.0056 \\
\hline 0.2929 & 0.3241 & -0.0312 & 0.0010 & 0.4264 & 0.3838 & 0.0426 & 0.0018 \\
\hline
\end{tabular}

\begin{tabular}{cccccccc}
\hline 0.3320 & 0.3237 & 0.0083 & 0.0001 & 0.6071 & 0.4216 & 0.1855 & 0.0344 \\
\hline 0.3163 & 0.2837 & 0.0326 & 0.0011 & 0.4753 & 0.3855 & 0.0898 & 0.0081 \\
\hline 0.3947 & 0.4090 & -0.0143 & 0.0002 & 0.2738 & 0.2857 & -0.0119 & 0.0001 \\
\hline 0.3662 & 0.3819 & -0.0157 & 0.0002 & 0.6130 & 0.7758 & -0.1628 & 0.0265 \\
\hline 0.1634 & 0.1816 & -0.0182 & 0.0003 & 0.3627 & 0.6842 & -0.3215 & 0.1033 \\
\hline 0.4325 & 0.4500 & -0.0175 & 0.0003 & 0.6340 & 0.7819 & -0.1479 & 0.0219 \\
\hline 0.7123 & 0.6925 & 0.0198 & 0.0004 & 0.6522 & 0.3789 & 0.2733 & 0.0747 \\
\hline 0.3247 & 0.3891 & -0.0644 & 0.0041 & 0.7107 & 0.6800 & 0.0307 & 0.0009 \\
\hline 0.3824 & 0.3680 & 0.0144 & 0.0002 & 0.7949 & 0.7795 & 0.0154 & 0.0002 \\
\hline 0.4749 & 0.4031 & 0.0718 & 0.0051 & 0.9000 & 0.8895 & 0.0105 & 0.0001 \\
\hline 0.4246 & 0.3978 & 0.0268 & 0.0007 & 0.4809 & 0.6725 & -0.1916 & 0.0367 \\
\hline 0.5952 & 0.5947 & 0.0005 & 0.0000 & 0.4989 & 0.3173 & 0.1816 & 0.0330 \\
\hline 0.5919 & 0.6318 & -0.0399 & 0.0016 & & Total & $\mathbf{0 . 4 1 8 2 7 2 1 5 5 7}$ \\
\hline & Total & $\mathbf{0 . 0 1 6 9 9 9 7 1 5 7}$ & & MSE & $\mathbf{0 . 0 2 6 1 4 2 0 0 9 7}$ \\
\hline & MSE & $\mathbf{0 . 0 0 0 9 9 9 9 8 3 3}$ & & Akurasi & & $\mathbf{8 8 \%}$ \\
\hline & & & & & & \\
\hline & & & & & & & \\
\hline
\end{tabular}

Dari hasil pelatihan dan pengujian yang dilakukan, didapatkan hasil penilaian model arsitektur yang terbaik yang dapat dilihat dari berbagai aspek seperti akurasi, jumlah epochs dan eror minimum. Untuk lebih jelasnya dapat dilihat pada gambar berikut:

Tabel 11. Rekapitulasi Model.

\begin{tabular}{llllll}
\hline Model & $5-10-1$ & $5-12-1$ & $5-14-1$ & $5-16-1$ & $5-18-1$ \\
\hline Epochs & 95344 & 71720 & 42360 & 34955 & 24062 \\
\hline MSE & 0.025251 & 0.020784 & 0.009334 & 0.018646 & 0.026142 \\
\hline Akurasi & $88 \%$ & $94 \%$ & $100 \%$ & $81 \%$ & $88 \%$ \\
\hline
\end{tabular}

Didapatkan model arsitektur 5-14-1 adalah arsitektur yang terbaik dengan akurasi kebenaran 100\% dan memiliki MSE terkecil sehingga model ini nantinya yang akan digunakan untuk memprediksi Pertumbuhan Industri Mikro dan Kecil Berdasarkan Provinsi.

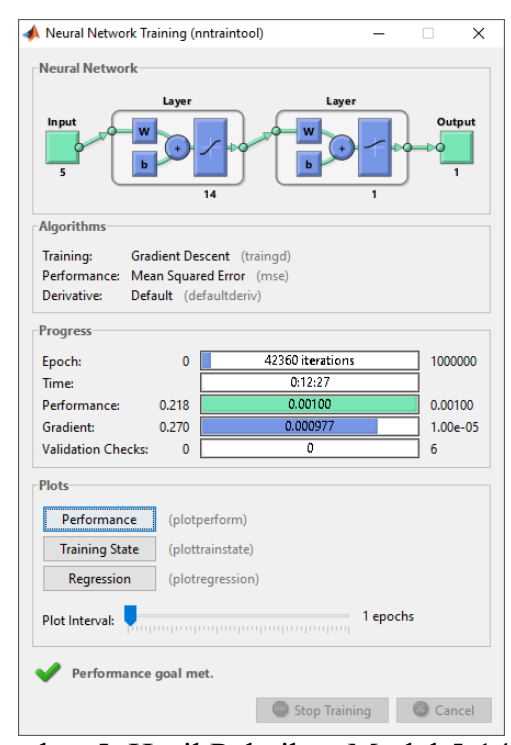

Gambar 5. Hasil Pelatihan Model 5-14-1. 

Industri Mikro dan Kecil Berdasarkan Provinsi

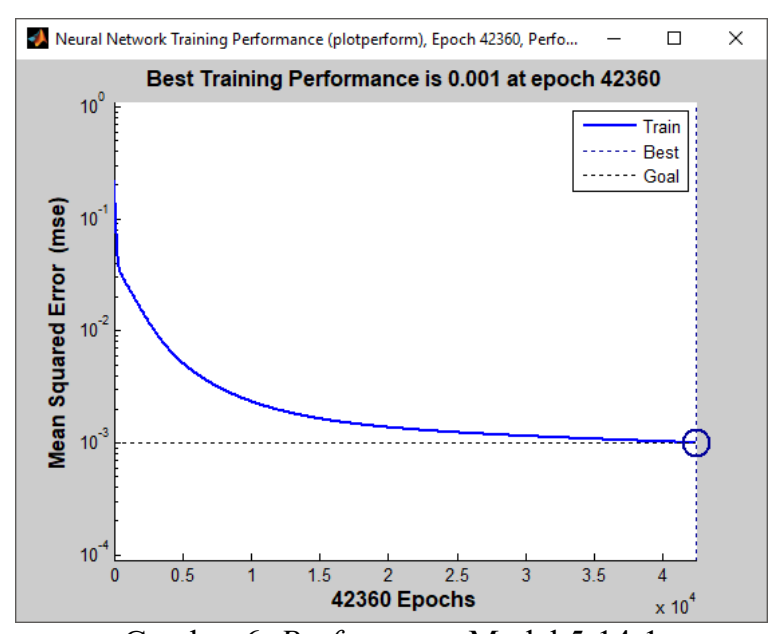

Gambar 6. Performance Model 5-14-1

D. Prediksi Pertumbuhan Industri Mikro dan Kecil Berdasarkan Provinsi

Setelah didapatkan model yang terbaik, makas selanjutnya adalah memprediksi Pertumbuhan Industri Mikro dan Kecil berdasarkan provinsi dengan menggunakan model yang terbaik. Adapun rumus yang digunakan untuk memprediksi Pertumbuhan Industri Mikro dan Kecil berdasarkan Provinsi adalah sebagai berikut :

$x=\left(\left(x^{\prime}-0,1\right)(x \cdot \max -x \cdot \min )\right)+x \cdot \min$.

Keterangan :

$\mathrm{x}^{\prime} \quad=$ Data Normalisasi

x.max $=$ Data Maksimal Asli

x.min = Data Minimal Asli

Untuk mengetahui prediksinya dapat dilihat pada sebagai berikut :

Tabel 12. Prediksi Pertumbuhan Industri Mikro dan Kecil

\begin{tabular}{clcccc}
\hline No & \multicolumn{1}{c}{ Propinsi } & Prediksi & $\begin{array}{c}\text { Y } \\
\text { Aktual }\end{array}$ & Error & Error ${ }^{\wedge} 2$ \\
\hline 1 & Aceh & 138.65 & 0.4935 & -0.0838730 & 0.007034684 \\
\hline 2 & Sumatera Utara & 124.84 & 0.3876 & 0.0702202 & 0.004930872 \\
\hline 3 & Sumatera Barat & 102.18 & 0.2138 & 0.0385230 & 0.001484021 \\
\hline 4 & Riau & 108.65 & 0.2635 & 0.0306492 & 0.000939371 \\
\hline 5 & Jambi & 123.58 & 0.3779 & -0.0416171 & 0.001731980 \\
\hline 6 & Sumatera Selatan & 105.31 & 0.2378 & 0.1229929 & 0.015127253 \\
\hline 7 & Bengkulu & 118.58 & 0.3396 & 0.0704153 & 0.004958313 \\
\hline 8 & Lampung & 134.50 & 0.4616 & -0.1141493 & 0.013030065 \\
\hline 9 & Kep. Bangka Belitung & 93.90 & 0.1503 & -0.0064924 & 0.000042152 \\
\hline 10 & Kep. Riau & 136.13 & 0.4742 & -0.0322921 & 0.001042777 \\
\hline 11 & DKI Jakarta & 175.78 & 0.7782 & -0.0612016 & 0.003745638 \\
\hline 12 & Jawa Barat & 113.63 & 0.3016 & -0.0097197 & 0.000094472 \\
\hline 13 & Jawa Tengah & 139.68 & 0.5014 & -0.0765119 & 0.005854065 \\
\hline 14 & DI Yogyakarta & 155.62 & 0.6236 & -0.2218043 & 0.049197133 \\
\hline & & & & \\
\hline & & & & & \\
\hline
\end{tabular}

\begin{tabular}{|c|c|c|c|c|c|}
\hline 15 & Jawa Timur & 152.42 & 0.5991 & -0.1788123 & 0.031973824 \\
\hline 16 & Banten & 184.75 & 0.8470 & -0.2818858 & 0.079459628 \\
\hline 17 & Bali & 160.87 & 0.6639 & -0.0740974 & 0.005490424 \\
\hline 18 & Nusa Tenggara Barat & 107.79 & 0.2568 & 0.0370616 & 0.001373563 \\
\hline 19 & Nusa Tenggara Timur & 179.51 & 0.8068 & -0.3641077 & 0.132574434 \\
\hline 20 & Kalimantan Barat & 126.60 & 0.4011 & -0.1355087 & 0.018362611 \\
\hline 21 & Kalimantan Tengah & 124.54 & 0.3853 & -0.0532934 & 0.002840184 \\
\hline 22 & Kalimantan Selatan & 177.15 & 0.7887 & -0.2733987 & 0.074746853 \\
\hline 23 & Kalimantan Timur & 132.84 & 0.4489 & 0.0176991 & 0.000313258 \\
\hline 24 & Sulawesi Utara & 119.77 & 0.3487 & -0.0402895 & 0.001623241 \\
\hline 25 & Sulawesi Tengah & 161.13 & 0.6659 & 0.1072984 & 0.011512955 \\
\hline 26 & Sulawesi Selatan & 117.51 & 0.3314 & 0.0649448 & 0.004217822 \\
\hline 27 & Sulawesi Tenggara & 177.56 & 0.7919 & -0.0289728 & 0.000839421 \\
\hline 28 & Gorontalo & 166.61 & 0.7079 & -0.2009010 & 0.040361225 \\
\hline 29 & Sulawesi Barat & 167.10 & 0.7117 & 0.0029252 & 0.000008557 \\
\hline 30 & Maluku & 165.10 & 0.6963 & 0.0882604 & 0.007789898 \\
\hline 31 & Maluku Utara & 178.56 & 0.7996 & 0.0265476 & 0.000704776 \\
\hline 32 & Papua Barat & 133.97 & 0.4576 & -0.0441062 & 0.001945360 \\
\hline 33 & Papua & 138.01 & 0.4886 & -0.1013501 & 0.010271849 \\
\hline & & & & Total & 0.535622677 \\
\hline & & & & MSE & 0.016230990 \\
\hline & & & \multicolumn{2}{|c|}{ Akurasi Kebenaran } & $91 \%$ \\
\hline
\end{tabular}

\section{KESIMPULAN}

Berdasarkan penelitian yang dilakukan maka dapat disimpulkan bahwa:

a) Setelah melakukan penelitian dengan bantuan Software Matlab, maka didapatkan arsitektur terbaik dari arsitektur 5-10-1, 5-12-1, 5-14-1, 5-16-1 dan 5-18-1 adalah arsitektur 5-14-1 yang dapat dilihat dari akurasi kebenaran dan jumlah MSE.

b) Dengan arsitektur 5-14-1 maka dapat diprediksi Pertumbuhan Industri Mikro dan Kecil berdasarkan Provinsi dengan performa $100 \%$.

c) Setelah melakukan prediksi maka didapat hasil prediksi Pertumbuhan Industri Mikro dan Kecil berdasarkan Provinsi dengan akurasi kebenaran 91\%.

\section{REFERENSI}

[1] Solikhun, Windarto, A.P., Handrizal \& Fauzan, M. (2017). Jaringan Syaraf Tiruan Dalam Memprediksi Sukuk Negara Ritel Berdasarkan Kelompok Profesi Dengan Backpropagation Dalam Mendorong Laju Pertumbuhan Ekonomi. Seminar Ilmiah Nasional Membangun Paradigma Kehidupan Melalui Multidisiplin Ilmu, pp. 14-31.

[2] Solikhun \& Safii, M. 2017. Jaringan Saraf Tiruan Untuk 
Memprediksi. J. Sains Komput. Inform., Vol. 1, No. 1, pp. 24-36.

[3] Windarto, A.P. (2017). Implementasi Jst Dalam Menentukan Kelayakan Nasabah Pinjaman Kur Pada Bank Mandiri Mikro Serbelawan Dengan Metode Backpropogation. J-SAKTI (Jurnal Sains Komput. dan Inform., Vol. 1, No. 1, pp. 12-23.

[4] Febrina, M., Arina, F. \& Ekawati, R. (2013). Peramalan Jumlah Permintaan Produksi Menggunakan Metode Jaringan Syaraf Tiruan (Jst) Backpropagation. J. Tek. Ind., Vol. 1, No. 2, pp. 174-179.

[5] Lesnussa, Y.A., Latuconsina, S. \& Persulessy, E.R. (2015). Aplikasi Jaringan Saraf Tiruan Backpropagation untuk Memprediksi Prestasi Siswa SMA (Studi Kasus : Prediksi Prestasi Siswa SMAN 4 Ambon). J. Mat. Integr., Vol. 11, No. 2, pp. 149-160.

[6] Sudarsono, A. (2016). Jaringan Syaraf Tiruan Untuk Memprediksi Laju Pertumbuhan Penduduk
Menggunakan Metode. Media Infotama, Vol. 12, No. 1, pp. 61-69.

[7] Kusmaryanto, S. (2014). Jaringan Saraf Tiruan Backpropagation untuk Pengenalan Wajah Metode Ekstraksi Fitur Berbasis Histogram. J. EECCIS, Vol. 8, No. 2, Desember 2014, pp. 193-198.

[8] Nurmila, N., Sugiharto, A. \& Sarwoko, E.A. (2005). Algoritma Back Propagation Neural Network untuk Pengenalan Karakter Huruf Jawa. J. Masy. Inform., Vol. 1, No. 1, pp. 1-10.

[9] Agustin, M. (2012). Penggunaan Jaringan Syaraf Tiruan Backpropagation untuk Seleksi Penerimaan Mahasiswa Baru pada Jurusan Teknik Komputer di Politeknik Sriwijaya. Univ. Diponegoro, Vol. 02, pp. 4-32. 